\title{
Study on the measures to improve the learning atmosphere of Independent college
}

\author{
Ting Liu, Xu Li \\ Department of Biology and Chemistry \\ Nanchang University College of Science and Technology Nanchang, China \\ e-mail: patrickheroin@sohu.com
}

\begin{abstract}
Construction of independent college learning atmosphere is directly related to the quality of talent cultivation, the survival and development of the college. Due to its own characteristics, independent college should fully know the importance of the construction of study style. The article researches the problems existing in learning atmosphere construction of the independent college, analyzes its reasons and puts forward countermeasures to strengthen and improve the learning atmosphere construction of independent college.
\end{abstract}

Keywords-independet college; learning atmosphere; measures; introduction

Under the background of the rapid development of economy in our country, in order to adapt to the needs of economic and social transformations, the independent college arises at the historic moment. As an important part of higher education in China, the government has began this pilot project since 1999. This new education style has been developing rapidly. Until March 25, 2010, the number of independent colleges registered in the ministry of education of the People's Republic of China is $322^{[1]}$. And these colleges have made important contributions for training the builders and successors of socialism with Chinese characteristics.

Learning atmosphere is a timeless theme, and it is the most precious wealth of a school, and it is also the most important index to measure its education levels. Construction of learning atmosphere is a very important aspect for the development of independent college. It not only affects the students' cultural and moral quality, but also affects the competition ability of independent college in a market economy. So to study the measures to improve learning atmosphere has the vital significance for the college to establish good talent cultivation quality and social reputation.

\section{SITUATION ANALYSIS ON THE STUDY ATMOSPHERE OF INDEPENDENT COLLEGE}

At present, the status of the study atmosphere construction of independent college has the following features:

\footnotetext{
A Both the Learning Enthusiasm and Initiative Being Weak
}

Most of the independent college students come from developed urban or region, their family economies are relatively rich, and family conditions are superior, so most of them have a sense of superiority. These students mostly are only children, they are well informed, their thoughts are active, their interests are extensive, and their overall qualities are relatively higher. But compared with other college students, independent college students' cultural foundation is relatively poor, so in terms of cultural learning enthusiasm , they are weaker, and their initiative is also not enough, so absenteeism, late for class, leave early is taken for granted to them, they prefer to cut school to take part in sports activities rather than active learning.

B. Without Correct Learning Habits and Attitudes

Independent college students should be said that their IQs are not abnormal, but their university entrance exam scores are 100 points lower than the students of the mother university ${ }^{[2]}$. The reason for this situation is that their learning methods and learning habits are not correct.

Bad habits are mainly manifested in the classroom, because their learning consciousnesses are not strong. They often whisper or do other things, and they not only do not listen to the teachers, but also influence the other students.

According to the reflection of many independent college teachers, in the class they had to spend quite a few times to maintain classroom discipline, otherwise the class will be difficult to go down. At the same time they also need to get the counselor's help to supervise and inspect the student $s$ attendance and urge the students to be serious in class.

\section{Lack of Self-Confidence and Learning Motivation}

Independent college students show a greater awareness and potential social activity ability. But as a result of their university entrance exam score is not ideal, their self-confidence in study was dampened. In common, they regard themselves incapable. Furthermore, because of being admitted to the in-dependent college through reducing the admission score, they lack confidence to the future, and doubt on the value of their diplomas and the treatment after graduation. So they lost confidence and interest in learning, commonly use the method of escape to face learning. D. Without Clear Goals in Study 
At present, independent college basically enroll their students in the third batch of undergraduate due to the limitation of enrollment policy. Therefore, relative to the mother university students, independent college students' cultural foundation is relatively weak, learning goals are not clear. Quite a number of independent college students are lack of clear learning objectives, and their learning interests are not strong, their hard study spirit and perseverance are relatively insufficient, they do not develop good study habits, lack of full of enthusiasm, so they arrange their study arbitrarily.

\section{THE MAIN REASONS INFLUENCING INDEPENDENT COLLEGE LEARNING ATMOSPHERE}

The influence factors of independent college learning atmosphere construction are various, including social, family, school and students' own aspects. Specific performance is as follows:

\section{A. Social Factors}

As the change of personal values, efficiency first principle replaced fair priority principle, values of valuing loyalty over money was replaced by utility values. It has a profound influence on the college students' world outlook and value outlook. The negative effects of market economy, such as money worship, consumerism and so on. It makes the whole society be full of impulse to seek quick success and instant benefits. People pursuit economic benefits one-sided without due respect for the knowledge and talent. As the result, Some students lost their learning motivations, and they feel confused about the future. So they are addicted to playing net games.

On the other hand, as the employment situation has become increasingly serious, a lot of university graduates encounter many difficulties in the job search process. It makes currently enrolled students lost their confidence on the future. So they lack interest and enthusiasm to study, and the learning atmosphere of independent college are facing hard-hit.

\section{B. Family Factors}

Because most of the students in independent colleges are an only child, their family social background, economic foundation and self-induction are superior, the self-righteous does not form good learning habits.

At the same time, parents are often only focus on the students' academic performance being good or bad, but ignore the psychological quality and the cultivation of cognitive ability exercise, which makes them lack the necessary learning self-discipline and autonomy. Once in the college, the lack of self-discipline selfmanagement will form a loose habits, relax to own request.

\section{College Factors}

- The independent college is an innovative way of running school in higher education, and is a new mode between the pubic universities and private universities. At the beginning period of the founding, the conditions of teachers, teaching facilities, administration and cadres' attitude are far from satisfactory to meet the requirement of student's needs ${ }^{[3]}$. The notable problems here are that the specialization level of teachers is comparatively low and the stability of the teaching team is rather poor, objectively affect the teaching effect. It has a positive influence on the construction and forging of a good study atmosphere. On the other hand, lacking of powerful and high-level management mechanism, lacking of fit right guide students learning methods and good atmosphere, further influence the formation of good learning atmosphere.

\section{MEASURES TO IMPROVE LEARNING ATMOSPHERE OF INDEPENDENT COLLEGE}

Learning atmosphere construction is a long-term and arduous task, independent college should combine the characteristics of the students and faculty, actively explore how to promote the construction of good style of study.

A.Establishing a Scientific Educational Philosophy, Abandoning Seeking Quick Success and Instant Benefits

A university without educational philosophy is just equal to a person without soul. Without scientific educational philosophy idea, the education behaviors of the university must be short-sighted, its target must be one-sided, and its development must be passive.

Scientific education concept has the guiding role to the development of colleges, and it has intrinsic leading role in the development of the school learning atmosphere.

If the private colleges want to realize the sustainable strategy of development, the key is to coordinate the college's various essential factors system operation.

These internal conditions of the system include the selection of private universities own value, the optimization of education resources, configuration of internal management system, etc.

The operators and managers of the independent colleges should, based on the sustainable development of the school, sets up the scientific concept of education, be in accordance with the law of education and abandon the utilitarian tendency in education. They should adhere to long-term of running from each aspect and abandon short-term behavior, especially strengthen the construction of study style, adhere to the normative and social responsibility based on the good quality of education and the high quality talent training quality, prevent the loss of social credibility,. They can not take the education quality in exchange for economic benefits to lead the loss of their long-term interests. So to study style construction, the basic problems and principles can not relax, and compromise, and the improvement of 
education quality should be considered as the first priority.

\section{B. Setting Up Strict Management System, Supervising}

\section{Students to Develop Good Study Habits}

Independent college students' learning habits were developed in middle school, especially some bad tempers are very difficult to correct. Strict management system is to enable students to develop good habits and the important guarantee of ideology and moral character. In terms of study style construction, the administration of independent colleges should strengthen the management from the following several aspects:

One is to formulate strict discipline and rules and regulations according to the reality of college, including student status management system, classroom discipline management system, leave system and examination discipline, etc.

The second is to strictly implement the rules and regulations. It is a good system. If you do not perform, it just is a dead letter, and makes no sense. Therefore, in terms of study style construction, strict enforcement of rules and regulations are very necessary.

Thirdly, we should stric the quality examination; strive to make the test objective, authentic, strict, and fair. We shoild make the students give up the idea of taking opportunistic, fraud ways in the exam thoroughly. Independent college should make strict management, relative elimination system on the basis of management, help students to develop good habits and ideology and moral character, form a good style of study and school spirit.

C. Actively Encouraging Students to Attend Postgraduate Entrance Examination, Building Up

Definite Study Aim,s Improving Initiative Drive to Study.

At present, our country graduate education scale expands unceasingly. The number of students who enter oneself for the post graduate entrance examination increased from 319 thousands in 1999 to 1.8 million in 2013, including the ependent college students. And the proportion of independent college students increased year by year. Since 2005, nearly the annual average $50 \%$ of the students studying in the biochemistry department of Nanchang university college of science and technology enter oneself for the postgraduate entrance examination and about $20 \%$ of the students were successfully admitted. This phenomenon is aroused the concern of the independent college teachers and managers more and more ${ }^{[4]}$.

To encourage independent college students to attend the postgraduate entrance examination, let the students set clear learning goals as soon as possible, arouse their intrinsic motivation are not only the ways of goal-directed teaching, but also the means of teaching quality control. In the three years of preparation process, they can often consciously plan their college career, seriously treat each course of study, and improve their learning ability. The preparation period is a process of self development no matter the student was successfully admitted or not.

Taking the students who prepare for the entrance examinations for postgraduates as an example, the teachers can effectively guide and encourage the other students to attend the postgraduate entrance examination over the years. They have done a lot of meticulous work, achieved excellent results, summed up the abundant experience. The practice proved that actively encourage the students to attend the examination has played a positive role in setting up the good study atmosphere, improving the students' active learning motivation and ability, and improving students' practice ability. The style of study and students training quality of the department of biochemistry, Nanchang university college of science and technology, is unanimously recognized by the experts both inside and outside school.

\section{ACKNOWLEDGMENT}

This subject comes from " the Project on Teaching Team of Basic Chemistry Course " financially supported by Nanchang University College of Science and Technology.

\section{REFERENCES}

[1] WANG Yu, "On Construction of Study Style in Independent Colleges," Journal of Jiangsu University o f Science and Technolo gy ( Social Science Editio n), vol. 10, pp. 108-111, Dec. 2010.

[2] XU Ming-lian, “The "Software”and"Hardware”about the Construction of study style in Private college”, Joumal of Jilin normal University(Humaniities \& Soeial Science Edition ), vol 6, pp. 100-103, Dec. 2008.

[3] LI Hai -xiang, HUANG Mei-ling, DAI Ren-yan, etc, “ On the Establishment of Learning Atmosphere in Independent School from the Perspective of Examination Management ", Journal of Anhui Univer sity of Technolog y ( Social Sciences), vol. 28, pp. 142-146, May. 2011.

[4] ZHUNing-bo1, HE Li-na ,LI Ya-wen. "The Research on the Motive of College Students Preparing for Postgraduate Entrance Examination ”, Journal of Liaoning Normal University ( Social Science Edition), vol 33, pp. 44-48, Nov. 2010. 